\title{
ANALYSIS OF STEEL I-BEAMS WITH RECTANGULAR WEB OPENINGS: EXPERIMENTAL AND FINITE ELEMENT INVESTIGATION
}

\author{
Samadhan G. MORKHADE, Laxmikant M. GUPTA \\ Department of Applied Mechanics, Visvesvaraya National Institute of Technology, \\ Nagpur 440 010, India
}

Received 08 July 2015; accepted 18 August 2015

\begin{abstract}
Steel I-shaped beams with web openings of shapes like hexagonal, circular and rectangular at regular intervals have been used since last 60-70 years. Therefore aim of this paper is to examine the behaviour of steel I-beams with rectangular web openings by performinganexperimental and parametric study. A parametric study based on finite element analysis consists of effect of fillet radius, aspect ratio of rectangular openings, stiffeners position around the openings and effect of positions of openings on load carrying capacities of steel beam with rectangular web openings was carried out by using a commercial finite element software ANSYS v.12. An overall study of such type of beam was carried out and results shows that rectangular openings having fillet radius either 2 times thickness of web or $25 \mathrm{~mm}$ (whichever is minimum), aspect ratio of 1.6 and reinforcement either in the form of horizontal or vertical stiffeners around the web openings found to be very effective. The fillet radius and stiffeners also affect the stress distribution around the corner regions of openings. Load carrying capacities of perforated beams are almost equal to plain-webbed beams, when openings are placed within middle two-third(neutral zone) of the span.
\end{abstract}

Keywords: steel I-beams; rectangular web openings; fillet radius; aspect ratio; stiffeners; perforated beams.

\section{Introduction}

Steel beams with web openings fabricated from standard hot rolled I-sections are commonly used in recent constructions to cover long spans. Openings of shapes like hexagonal, circular and rectangular are general (Fig. 1). Provision of openings in steel beams create flexibility in the use of the floor area, flexibility in running services such as ventilation ducts, greater flexural stiffness, larger section modulus, optimum self weight-depth ratio, economic construction, and they have scene of beauty as well (Chung et al. 2003).

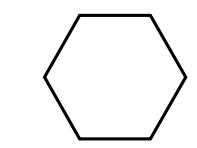

Hexagonal opening

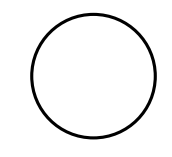

Circular opening

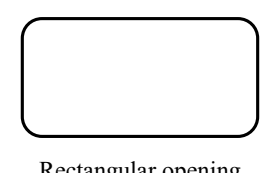

Rectangular opening
Fig. 1. Various types of web openings
But on the other hand, the provision of openings in steel beams introduces typical failure modes depending on geometry of the beams, size of web openings, spacing between openings, web slenderness, type of loading, quality of welding, and lateral restraint conditions. These failure modes are:

1. Flexural mechanism;

2. Web post buckling due to shear force;

3. Web post buckling due to compression force;

4. Lateral torsional buckling;

5. Vierendeel mechanism;

6. Rupture of welded joints;

7. Local web buckling;

8. Web distortional buckling (Kerdal, Nethercot 1984).

Extensive experimental and numerical investigations were found in the literature highlighting the dis-

Corresponding author:

S. G. Morkhade E-mail: samadhanmorkhade@gmail.com 
tortional buckling behaviour of doubly symmetric steel I-sections (Bradford 1998; Zirakian 2008). The test results provided by Zirakian and Showkati (2006) have provided useful information regarding the behaviour of castellated steel beams in the form of failure loads, failure modes, load-lateral deflection curves and loadstrain curves. Further numerical investigations have been carried out on the inelastic lateral torsional buckling of castellated beams (Mohebkhah 2004). Based on the test results (Zirakian, Showkati 2006), a nonlinear finite element model was developed for analyzing the interaction of buckling modes in castellated steel beams (Ellobody 2011). Compared with fixed profile and cutting pattern of castellated steel beams, cellular steel beams provide greater flexibility in their finished depth, cell diameter and cell spacing.

Numerous researchers have performed study to examine web opening shapes of perforated steel sections in order to provide a better understanding of the stress distribution in the surrounding area of the web openings, under certain types of loading (Chung et al. 2001; 2003). Generally speaking, round openings perform better than rectangular openings of similar or somewhat smaller size (Redwood, McCutcheon 1969). This improved performance is due to the reduced stress concentrations in the regions of the openings and the relatively larger web regions in the tees that are available to carry shear. The key findings of a comprehensive finite element investigation into the structural behaviour of steel beams with web openings of various shapes and sizes are presented, and a generalized design rule with a set of moment-shear interaction curves based on the finite element results is also developed for practical applications (Chung 2012). The effect of the cellular beam configuration on the deflection has been investigated by using the three-dimensional finiteelement analysis of 408 cellular beams. Cross-section dimension, beam slenderness, opening size and opening spacing arefound to affect the stiffness of the analytical load-deflection curve (Pattamad, Thaksin 2013).

But sometime it is the structural needs to used rectangular web openings instead of circular or hexagonal, therefore keeping this point in mind here an attempt is made to analyze the steel I-beams with rectangular web openings. Different aspects considered for parametric study are the effect of corners radius, as stress concentration is high around the corners regions, aspect ratio of web openings, and effect of stiff- eners around the openings and the load carrying capacities of steel beams with rectangular web openings by changing the positions of openings.

\section{Objectives and importance of research}

A steel I-beam with different types of web openings makes the majority of industrial structures globally, wherein the different technical utilities e.g. A.C ducts, electric cables, water carrying pipes etc. can be incorporated. As discussed previously that inclusion of web openings makes the behaviour of such beams different than plain-webbed beams. Numerous literatures are available on beams with hexagonal and circular web openings, but very few related to the beams with rectangular web openings. Therefore it becomes necessary to investigate the behaviour of steel beams with rectangular web openings. The investigation has been divided in to two parts:

a. Experimental investigation based on actual testing of models of steel beams with rectangular web openings having different aspect ratio.

b. Finite element investigation consists of different parameters such as; effect of corner radius, aspect ratio, and stiffeners around the openings regions and load carrying capacities of such beams by changing the position of openings etc.

\section{Experimental program}

\subsection{Material properties}

Tensile test coupons cut from the flange and web plates of the section segments were tested in order to determine the material properties required for the numerical modelling of the beams with web openings. For all of the test specimens, only four coupons, i.e. two from the flange plate and two from the web plate, were cut out for the material test, as all test specimens made from the same section. They were tested on UniversalTesting Machine of $500 \mathrm{kN}$ capacity, at material testing laboratory (Fig. 2). The results, yield stress, ultimate stress and modulus of elasticity obtained from the coupons test are given in Table 1.

\subsection{Experimental test procedure}

Steel beams with rectangular web openings with two aspect ratio (defined as the ratio of length of opening to depth of opening, L/D) were tested to failure. The details regarding the dial gauges, the experimental test 
Table 1. Material properties of the test specimens

\begin{tabular}{|c|c|c|c|c|c|}
\hline Specimen & Actual Width $(\mathrm{mm})$ & Actual Thickness (mm) & $\sigma_{y}(\mathrm{MPa})$ & $\sigma_{u}(\mathrm{MPa})$ & $\mathrm{E}(\mathrm{MPa})$ \\
\hline \multicolumn{6}{|c|}{ Flange } \\
\hline S1F & 20 & 5 & 376 & 487 & $1.98 \times 10^{5}$ \\
\hline S2F & 22 & 5 & 352 & 495 & $2.10 \times 10^{5}$ \\
\hline \multicolumn{3}{|c|}{ Overall Average Values } & 364 & 491 & $2.04 \times 10^{5}$ \\
\hline \multicolumn{6}{|c|}{ Web } \\
\hline S1W & 20 & 4.7 & 322 & 450 & $1.96 \times 10^{5}$ \\
\hline S2W & 20 & 4.7 & 337 & 430 & $2.01 \times 10^{5}$ \\
\hline \multicolumn{3}{|c|}{ Overall Average Values } & 329.5 & 440 & $1.99 \times 10^{5}$ \\
\hline
\end{tabular}

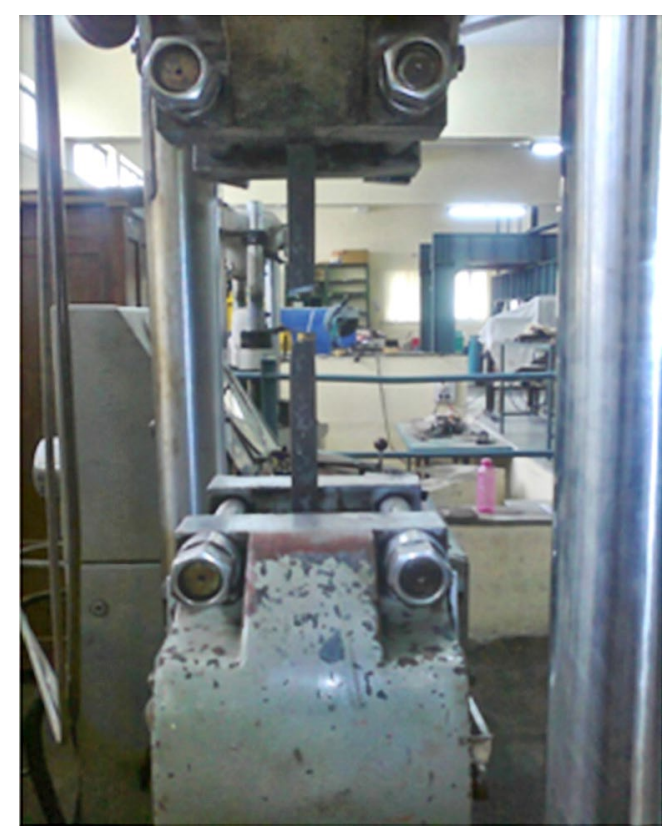

Fig. 2. Typical view of the coupon test set-up

set-up, position of proving ring and loading jack are highlighted in Figures 3 and 4. The depth of the beams were kept constant in order to study the behaviour of web post exclusively. For all beams, overall depth was maintained at $100 \mathrm{~mm}$ with nominal top and bottom flange width of $55 \mathrm{~mm}$ and the corresponding nominal thickness of flange $5 \mathrm{~mm}$ and that of web is $4.7 \mathrm{~mm}$. Transverse stiffeners were made of flat plates $25 \mathrm{~mm}$ wide and $5 \mathrm{~mm}$ nominal thickness.

The beam having simply supported boundary conditions (with no lateral restrained to top flange i.e. laterally unrestrained) was set up in the loading frame with sufficient care taken to ensure that the specimen was correctly positioned in the loading frame and the mid point of the beam was coinside with the centre line of the loading hydraulic jack. The specimen was heavily gauged, as shown in Figures 3 and 4, in an at-

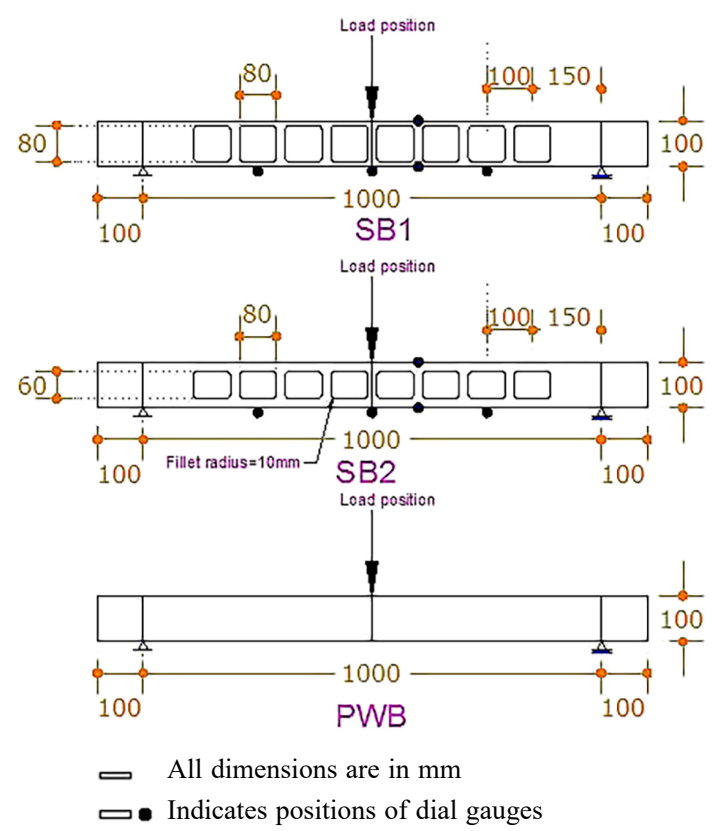

Fig. 3. Details of the test beam

tempt to identify a primary mode of failure i.e. either buckling load for the web post, the formation of plastic hinges, or local buckling of the flange. Prior to application of load on the specimen, all the dial gauges were calibrated properly. Before the actual test, a small preload not exceeding 5 percent of the expected ultimate load was applied gradually and removed in order to eliminate any slack in the support system so that the specimen would be properly seated on the supports.

The loading and unloading process was repeated a few times and this procedure also helped to check whether the dial gauges functioned properly or not. Readings were initiated after ensuring that all instruments worked satisfactorily. The specimen was loaded first up to $20 \%$ of the expected failure load and then unloaded to zero value. It was observed that the deflection readings reached the initial values when unloaded. 


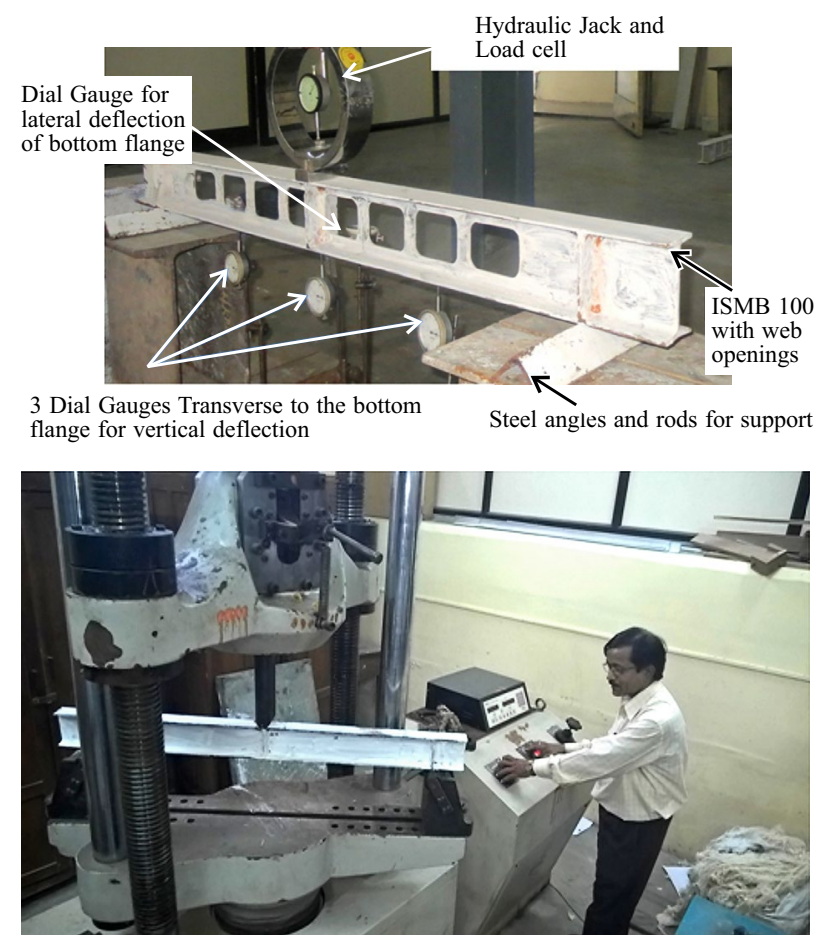

Fig. 4. Experimental test-set of beam

The procedure was repeated up to $30 \%$ of the expected failure load and the specimen was finally loaded to failure by increasing the load gradually by a predetermined increment.The five dial gauges were installed, three for measurement of vertcal deflection placed at $\mathrm{L} / 4, \mathrm{~L} / 2$ and $3 \mathrm{~L} / 4$ respectively and two for measurement of lateral deflection of top and bottom flange respectively as shown in Figures 3 and 4 . The beam was further tested for failure. After the maximum load was attained and unloading occurred with increase in beam deflection, the load was then removed. The ultimate load and the mode of failure for each of the specimens were noted. The same test procedure was adopted for all the specimens.

\subsection{Discussion of the test results}

The ultimate loads obtained from the experiments and finite element analysis is presented in Table 2. Variations of mid-span vertical deflection with the applied load for typical beams are as it is shown in the Fig- ures 5, 6 and 7 for beam tested such as steel beams with rectangular web openings (SB1, SB2) and plain webbed beam $(\mathrm{PWB})$ respectively. Figure 8 shows the comparison of experimental and finite element results related to the stress concentration around thecorner regions. It has been observed from the experiments that stiffness and ultimate load of the beams decrease with an increase in the opening area along with the position of the openings. Comparison between the ultimate loads obtained experimentally and those predicted by the finite element analysis presented in Table 2 , shows that the finite element solutions are relatively close to the corresponding experimental results. The discrepancy between the two curves might be due to the inability of the ANSYS program. The main reason responsible for difference in experimental and numerical failure loads in SB1, SB2 and PWB is mainly due to human error in experimental work and stiffness of members. The stress concentration shown in Figure 8 is nothing but the failure due to Vierendeel mechanism of steel beam with web openings, which is one of the prime failure modes in case of steel beams with web openings.

\section{Parametric study}

A three-dimensional (3D) finite element model was developed to simulate the behaviour of steel I-beams with rectangular web opening configurations, having an I-shaped cross-section. Modelling was conducted

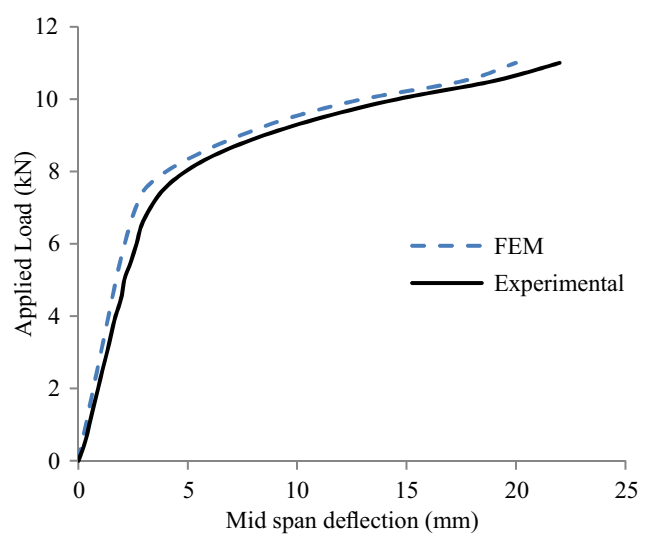

Fig. 5. Load vs mid span deflection for beam SB1

Table 2. Comparison of experimental and finite element ultimate load

\begin{tabular}{|c|c|c|c|c|c|c|}
\hline \multirow{2}{*}{ Specimens } & \multirow{2}{*}{$\begin{array}{c}\text { Span of } \\
\text { Beams }(\mathrm{m})\end{array}$} & \multirow{2}{*}{$\begin{array}{c}\text { Aspect } \\
\text { Ratio }\end{array}$} & \multicolumn{2}{|c|}{ Ultimate load $\mathrm{Pu}(\mathrm{kN})$} & \multirow{2}{*}{$\mathrm{Pu}_{\text {Ansys }} / \mathrm{Pu}_{\text {Experimental }}$} & \multirow{2}{*}{ Primary failure modes } \\
\cline { 4 - 5 } & & $\mathrm{Pu}_{\text {Ansys }}$ & $\mathrm{Pu}_{\text {Experimental }}$ & & \\
\hline $\mathrm{SB} 1$ & 1.0 & 1.0 & 11.0 & 12.00 & 0.92 & Vierendeel mechanism \\
\hline $\mathrm{SB} 2$ & 1.0 & 1.3 & 17.90 & 18.50 & 0.92 & Vierendeel mechanism \\
\hline $\mathrm{PWB}$ & 1.0 & - & 45 & 49.3 & 0.97 & Bending at load application point \\
\hline
\end{tabular}




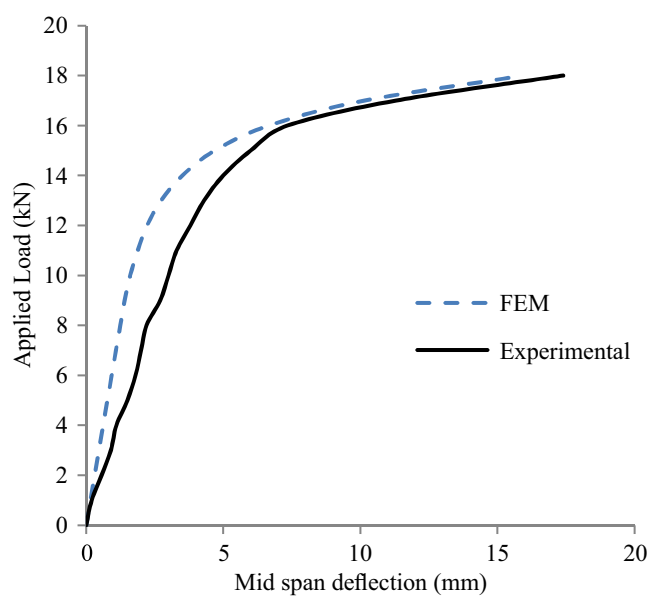

Fig. 6. Load vs mid span deflection for beam SB2

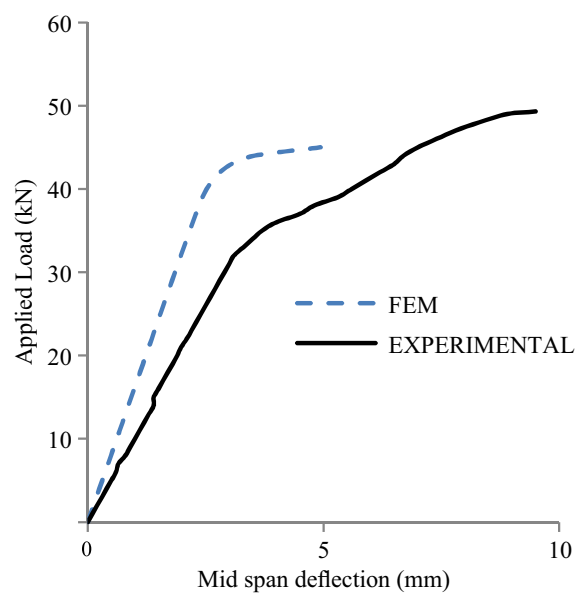

Fig. 7. Load vs deflection curve for plain web-beam (PWB) a)

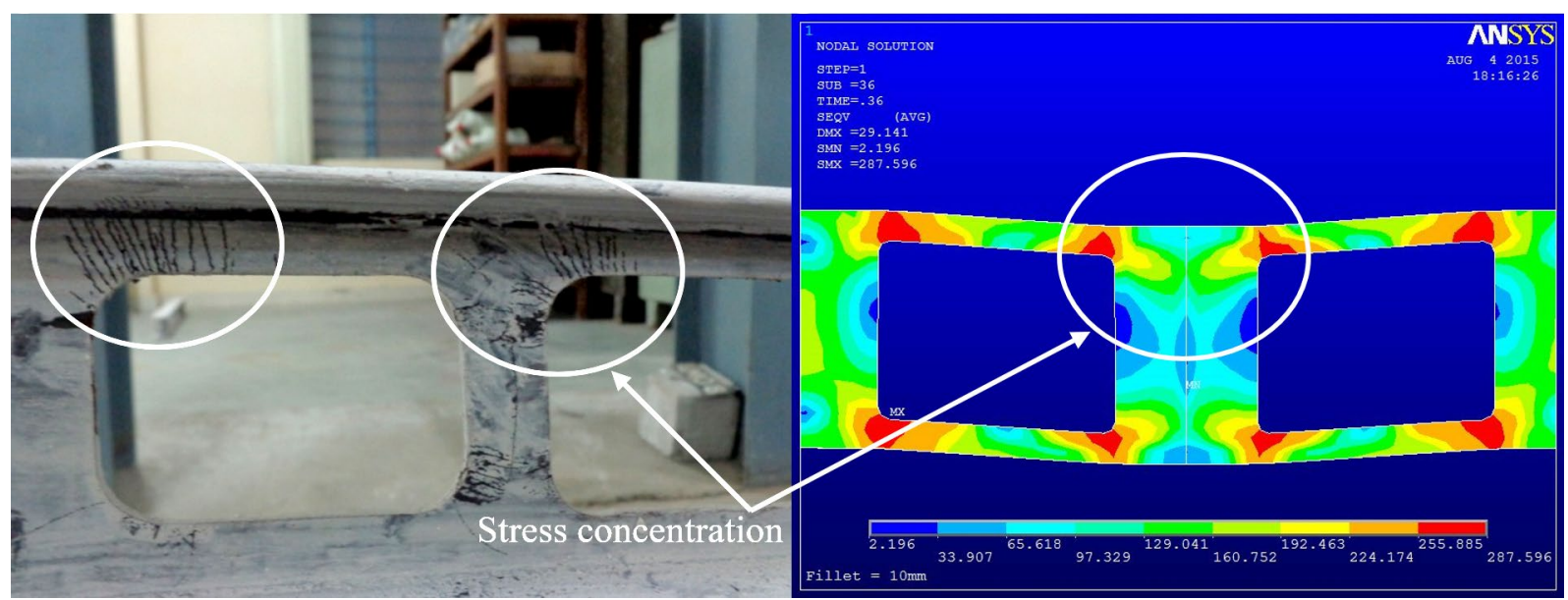

Fig. 8. Stress concentrations around the corners region of openings (Vierendeel mechanism): a - experimental; b - FEM

using the general-purpose finite element software package ANSYS (version, 2012). The summary of finite element model is as follows:

- Geometrical details of analyzed beams are simulated using the four-noded shell element (SHELL 181). This element has six degrees of freedom at each node, three translations and three rotations. Besides, SHELL 181 is suitable for modelling thin to moderately thick shell structures;

- A bilinear stress-strain curve was used for material modelling in ANSYS software;

- Large deformation effect was considered in the analysis to account for geometrical non-linearity in the model;

- Von Mises yield criteria has been considered in numerical analysis which is suitable for material like steel;

- Solver by iterations according to full NewtonRaphson procedure;
- The load was applied as pressure and point load on top flange;

- The material properties as shown in table 1 are used in the analysis.

After establishing the accuracy of finite element model, a parametric study was carried out considering the different factors that affects the structural behaviour of steel I-beams with rectangular web openings. The objective of this section is to carry out non linear finite element analysis of the steel beams with rectangular web openings by varying the fillet radius, aspect ratio, stiffeners around the web openings and load carrying capacity of the beams by changing the positions of openings. Nonlinear finite element models of these steel beam with rectangular web openings specimens are built to determine maximum values of ultimate load, locations of stress, strain and displacement concentrations under point and uniformly distributed loading. 


\subsection{Verification of finite element model}

To verify the performance of the $3 \mathrm{D}$ finite element model, the model is used to carry on an eigenvalue analysis (elastic properties of steel beam i.e. $E=$ $200 \mathrm{GPa}$ and $\mu=0.3$ are considered in the analysis) of various beams to identify their critical moment values that correspond to a lateral torsional buckling mode of failure. The verification phase starts with evaluating critical buckling moment of plain-webbed (i.e. no holes in the web) simply supported beams ranging from ISMB100 to ISMB600 and subjected to uniform end moment. Figure 9 shows the simulation of uniform end moments in ANSYS. The finite element predictions are then compared to the analytical solution of the critical moment $M_{c r}$ (Timoshenko 1961).

$$
M_{c r}=\sqrt{\frac{\pi^{2} E I_{y}}{(k L)^{2}}\left(G I t+\frac{\pi^{2} E I_{w}}{(k L)^{2}}\right.},
$$

where $\mathrm{L}$ is the unbraced length of the beam and $I_{y}$ is the minor moment of inertia of the cross-section, $G I_{t}$ and $E I_{w}$ are torsional and warping rigidities of the

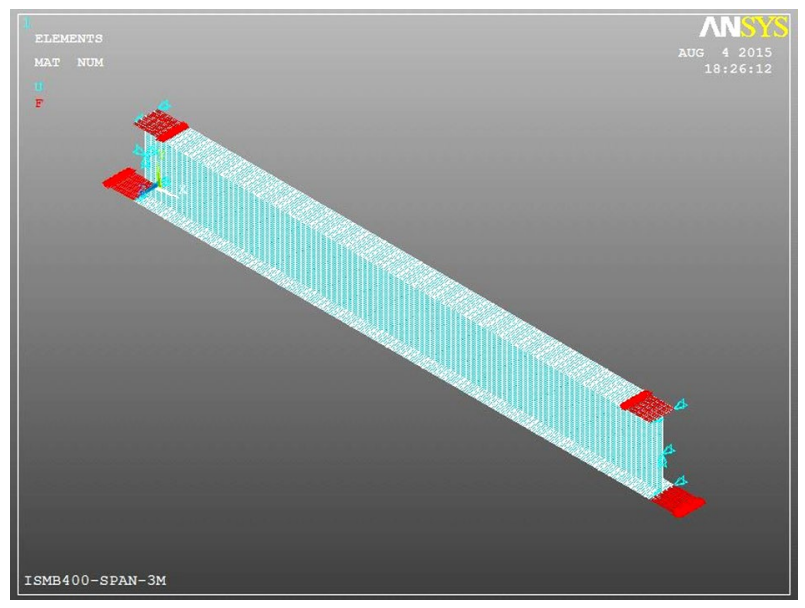

Fig. 9. Simulations of end moments beam respectively. The results of the quantitative comparison between analytical solutions and finite element predictions are summarized in Table 3, indicating an excellent agreement with an absolute maximum error that does not exceed $0.86 \%$.

\subsection{Effects of fillet radius}

The stress concentration at the corners of rectangular web openings was very critical. Openings having a sharp edge (zero fillet radius) showed very high stress concentration due to a reduction in the area at that location. Secondly, there is a possibility that opening may get crack due to the sharp edge of openings. Therefore, here an attempt is made to see the effect of variation of fillet radius on stress concentration around the corners regions of openings. Totally six fillets radius varying from $0 \mathrm{~mm}$ to $25 \mathrm{~mm}$ were studied, see Figure 10 . Figures 11 and 12 shows the load vs mid-span deflection curves for different fillet radius for point load and uniformly distributed load respectively, whereas; Figure 13 shows the von-Mises stresses around the corners region of openings for different fillet radius.

\subsection{Effect of aspect ratio}

Aspect ratio is defined as the ratio of length to depth (L/D) of opening. In the present study the aspect ratio of rectangular web opening is varied from 1.0 to 2.0 and the results has been plotted to observe the variation of applied load vs mid-span deflection for the point load and uniformly distributed load respectively.

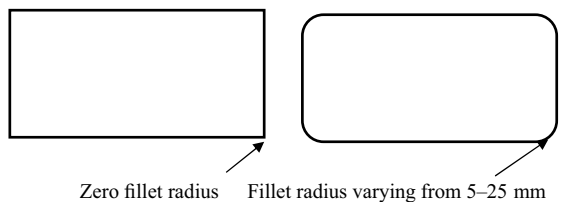

Fig. 10. Fillet radius

Table 3. Comparison between finite element and analytical buckling moment for plain-webbed beam

\begin{tabular}{|c|c|c|c|c|c|}
\hline Sr. No. & Section & Span L $(\mathrm{m})$ & $\begin{array}{c}M_{c r}(\mathrm{kN}-\mathrm{m}) \\
(\mathrm{FEM})\end{array}$ & $\begin{array}{c}M_{c r}(\mathrm{kN}-\mathrm{m}) \\
\text { (ANALYTICAL) }\end{array}$ & \begin{tabular}{c} 
\% Error \\
\hline 1
\end{tabular} \\
\hline 2 & ISMB-100 & 3 & 11.60 & 54.40 & 0.86 \\
\hline 3 & ISMB-200 & 3 & 54.13 & 176.13 & 0.44 \\
\hline 4 & ISMB-300 & 3 & 176.90 & 343.83 & 0.84 \\
\hline 5 & ISMB-400 & 3 & 346.74 & 792.24 & 0.18 \\
\hline 6 & ISMB-500 & 3 & 793.68 & 1802.64 & 0.08 \\
\hline
\end{tabular}




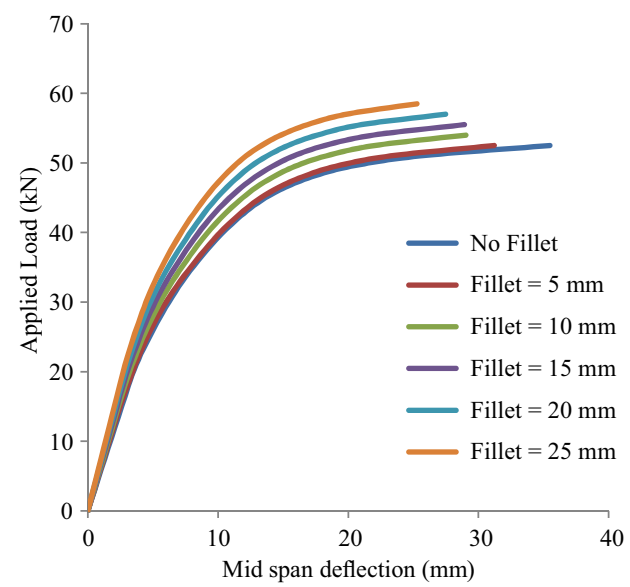

Fig. 11. Load vs mid span deflection for beam of different fillet radius subjected to point load

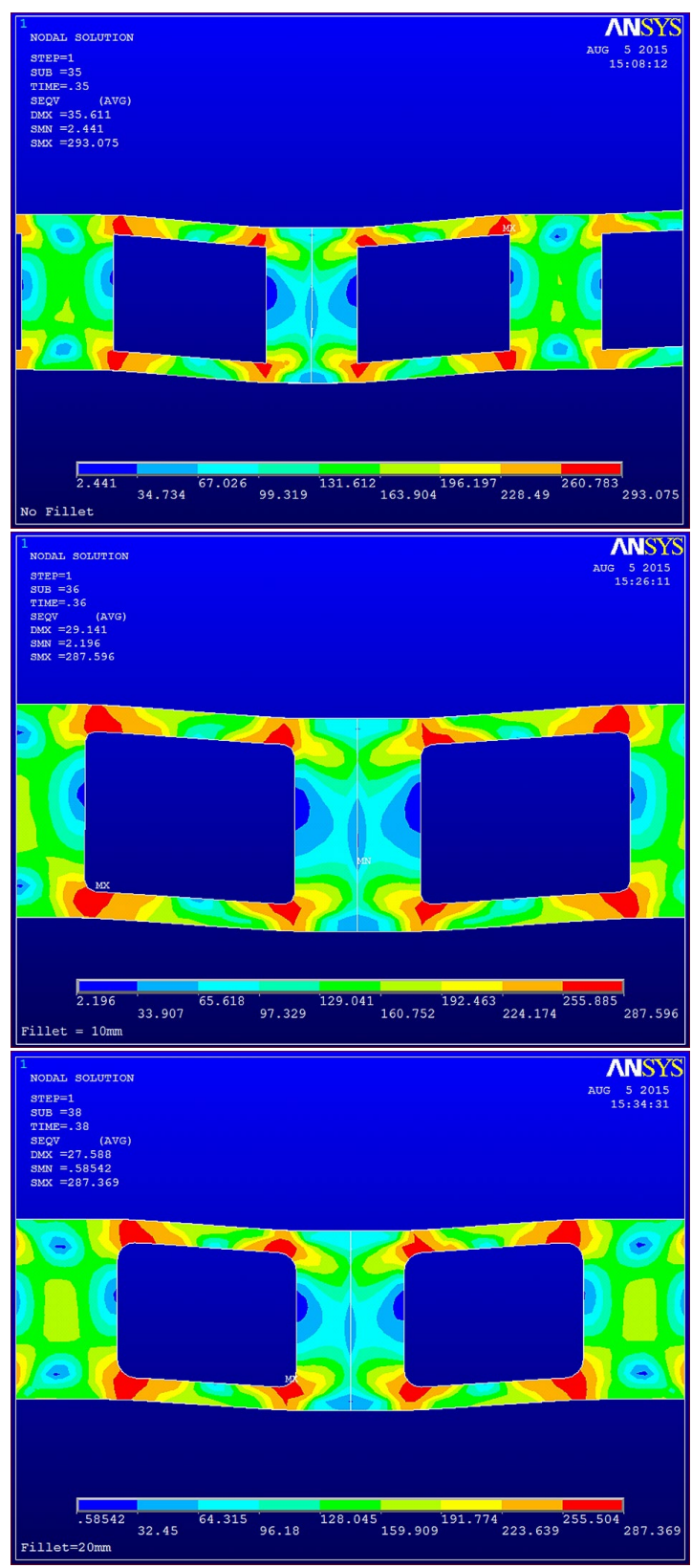

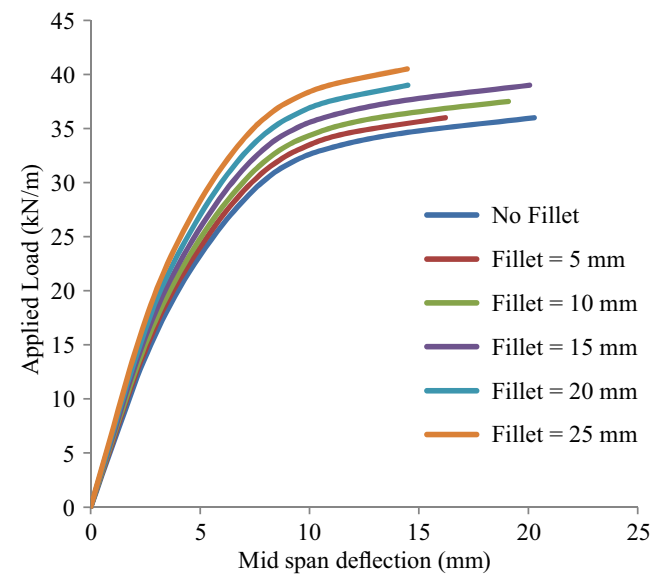

Fig. 12. Load vs mid span deflection for beam of different fillet radius subjected uniformly distributed load

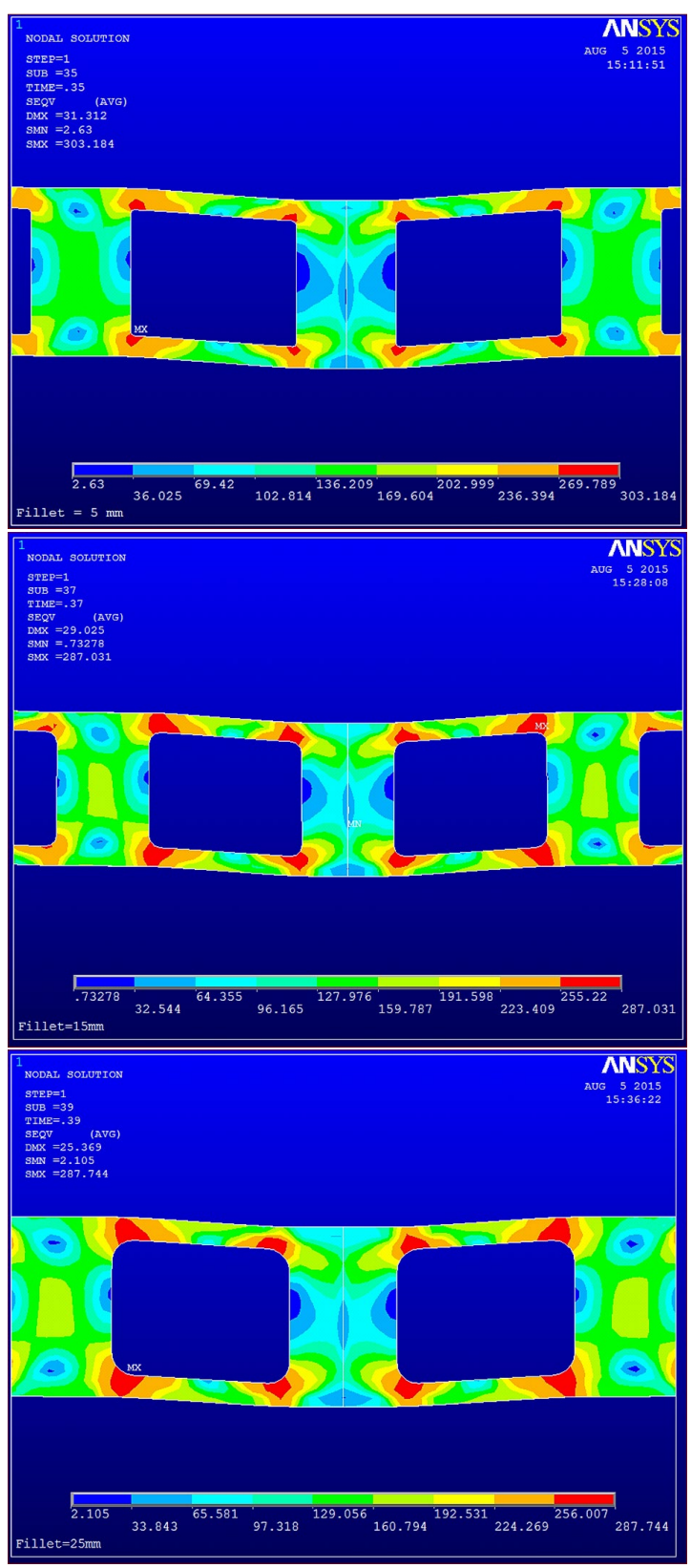

Fig. 13. Von-Mises stress distribution around the corners of opening for different fillet radius 
Though the aspect ratio of opening is changing, but the cross-sectional area of opening for each aspect ratio is almost kept same. Figures 14 and 15 shows the load vs mid-span deflection graph for different aspect ratio of openings subjected to point load and uniformly distributed load.

\subsection{Effect of reinforcement (Stiffeners)}

If the strength of a beam in the vicinity of a web opening is not satisfactory, the capacity of the member can be increased by the addition of stiffeners (reinforcement). Type of reinforcement which usually takes the form of longitudinal steel bars or flats welded above and below the opening (U.S. Steel Corporation 1986; Shrivastava, Redwood 1977). To be effective, the bars must extend past the corners of the opening in order to ensure that the yield strength of the bars is fully

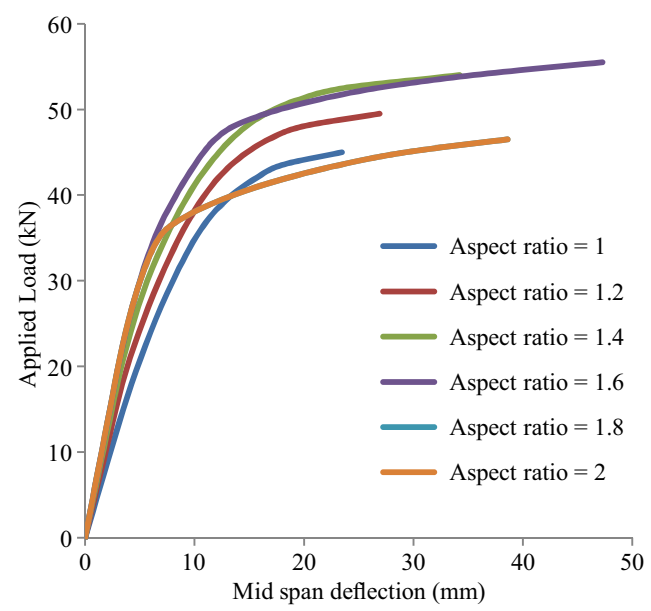

Fig. 14. Load vs mid span deflection for beam of different aspect ratio subjected to point load

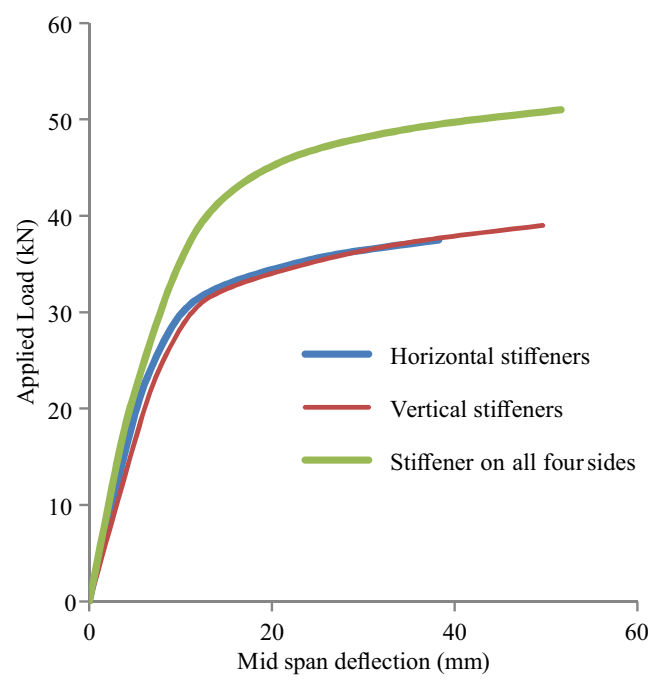

Fig. 16. Load vs mid span deflection for beam of different stiffeners position subjected to point load developed. These bars serve to increase both the primary and secondary flexural capacity of the member. Figures 16 and 17 show the load vs mid span deflection graph for horizontal stiffeners, vertical stiffeners and stiffeners on all sides of web openings subjected to point load and uniformly distributed load.

\subsection{Results and discussion}

As it was mentioned previously, the use of an appropriate corner radius on the beam web opening edge region is extremely important for beams with square and rectangular openings since it reduces the stress concentration around those regions and contributes for a better stress redistribution along the steel beam web opening see Figure 13. Using an edge corner radius equal to two times the web thickness or $25 \mathrm{~mm}$, whichever is minimum has been found to be very ef-

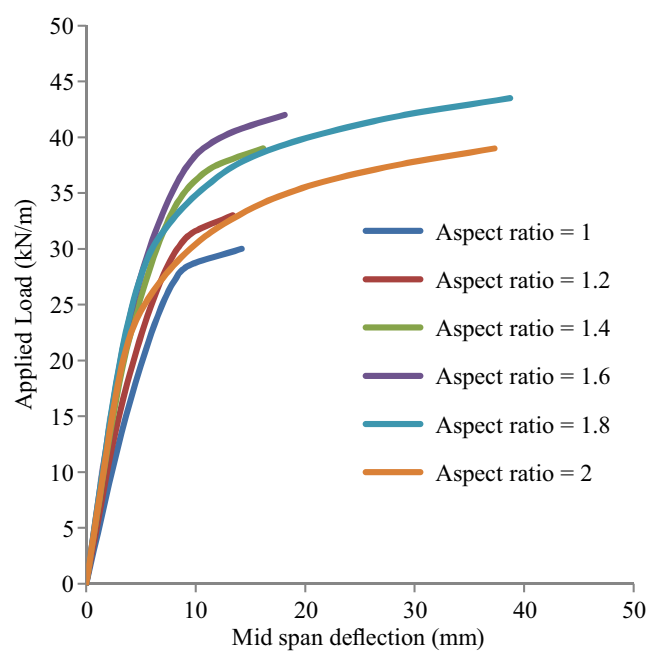

Fig. 15. Load vs mid span deflection for beam of different aspect ratio subjected to uniformly distributed load

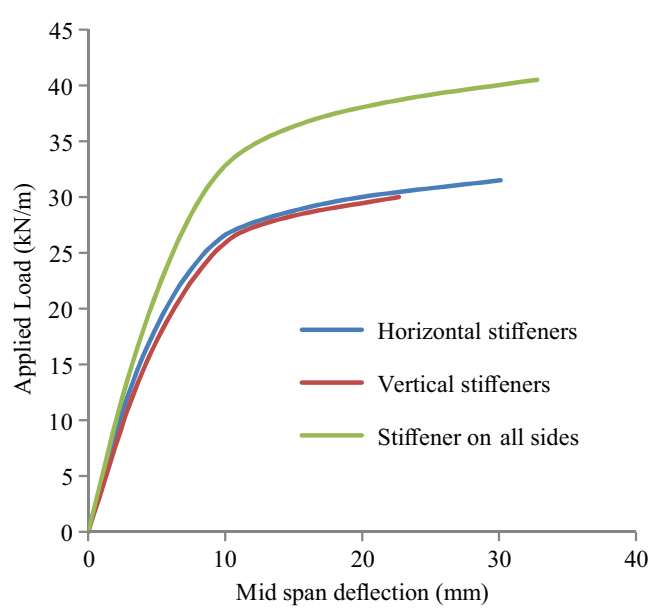

Fig. 17. Load vs mid span deflection for beam of different stiffeners position subjected to uniformly distributed load 
fective for reduce stress concentration. It can be easily observed that an increase of opening edge corner radius was very efficient for increasing the ultimate loads of beam with rectangular web openings as shown in Figures 11 and 12. From Figures 13 and 14 it can be concluded that the rectangular web openings having proper aspect ratio (1 to 1.6) perform better during loading. Figures 15 and 16 indicate that the presence of the longitudinal stiffeners enables a better performance along the web openings contributing to an increase of the beams load carrying capacity. It could be observed that the use of longitudinal stiffeners along the openings region shows a considerable advantage when compared to beams with non-stiffened web opening solutions. The stiffened solutions enabled an increase of the beam ultimate bending capacity around thrice and twice the unstiffened solutions for beams with rectangular and square openings, respectively.

\section{Investigation of neutral zone into steel beam with web openings}

Having established the accuracy of the finite element method to predict the load carrying capacity, a parametric study was carried out to investigate the neutral zone of steel beam with web openings. Some national standards, such as the British Standard (BSI 2000) and the Canadian Standard (CSA 2001), AISC-LRFD (1999) provide simplified rules for opening design in order to avoid weakening of the beam. However, these rules cover a wide range of possibilities and therefore they are very conservative and in general restrict the openings to the middle three/fourth $(3 \mathrm{D} / 4)$ of the beam depth and to the two central quarters of the beam span. By fixing some parameters, it would be possible to get more flexible and economical results for typical situations in the floors of buildings. The principal aim of this section is to investigate the region where a concentric opening with certain size and shapes does not affect beam strength. Knowing the location of this region, called the neutral zone see Figure 18 , it is possible to design web openings without considering the beam net section, which dispenses of analytical calculation methods. The neutral zone depth, $h_{n z}$, is symmetrically positioned with respect to the centroid of the steel section and can be defined as twice the web opening half-depth plus the opening eccentricity. Clearly, for openings symmetrically located with respect to the centroid of the steel section

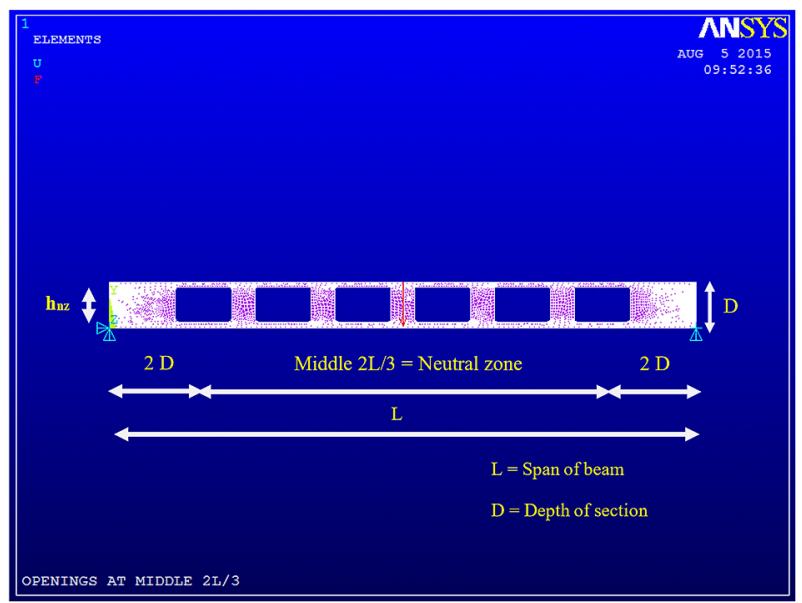

Fig. 18. Neutral zone in steel beam with web openings

(concentric opening), $h_{n z}$ is the opening depth itself. A typical section of ISMB- 400 of span $5 \mathrm{~m}$ having different position of openings configurations see Figure 19, subjected to concentrated load has been considered in the present study. The openings having aspect ratio 1.6 and fillet radius $25 \mathrm{~mm}$ are considered in the study. From the parametric study it can be seen that, the load-deflection response of the beam provided with openings within middle $2 \mathrm{~L} / 3$ (neutral zone) of span, is almost similar to the plain-webbed beam as shown in Figure 20.

\section{Conclusions}

The aim of this study was to evaluate the strength of steel beam with rectangular web openings; therefore experiments carried out on steel beams with rectangular web openings are presented. Beams with two different aspect ratio and web openings area have been tested to failure. In this study, effect of fillet radius, aspect ratio and stiffeners of rectangular web openings was carried out. Based on the results from the experimental and finite element studies the following conclusions can be made for steel beams with rectangular web openings:

- The experimental and FE results show that stress concentration around the corners regions of openings is critical. The high stress zone around the corners indicates that formation of four plastic hinges (Vierendeel mechanism) in those regions, which is one the prime failure modes in the steel beam with web openings.

- Test results show that the ultimate load capacity and the stiffness decrease with increase in opening area. Failure modes are similar for all the beams with rectangular web openings. 
- Fillet (corner) radius of 2 times the thickness of web or $25 \mathrm{~mm}$, whichever is minimum is found to be effective. Therefore, instead of providing sharp corner edge openings a minimum filletradius of 2 times the thickness of web or $25 \mathrm{~mm}$ should be provided.

- Aspect ratio in the range of 1-1.6 should be provided with the rectangular web openings.

- Though stiffness of the beam has increased when stiffeners are provided on all sides of the opening, but it is found that either horizontal or vertical stiffeners around the openings found to be very effective.

- The best location for web openings is middle $2 \mathrm{~L} / 3$ (neutral zone) of span. If web openings are provided within this region's the response of beams with web openings is almost similar to the plain-webbed beam.
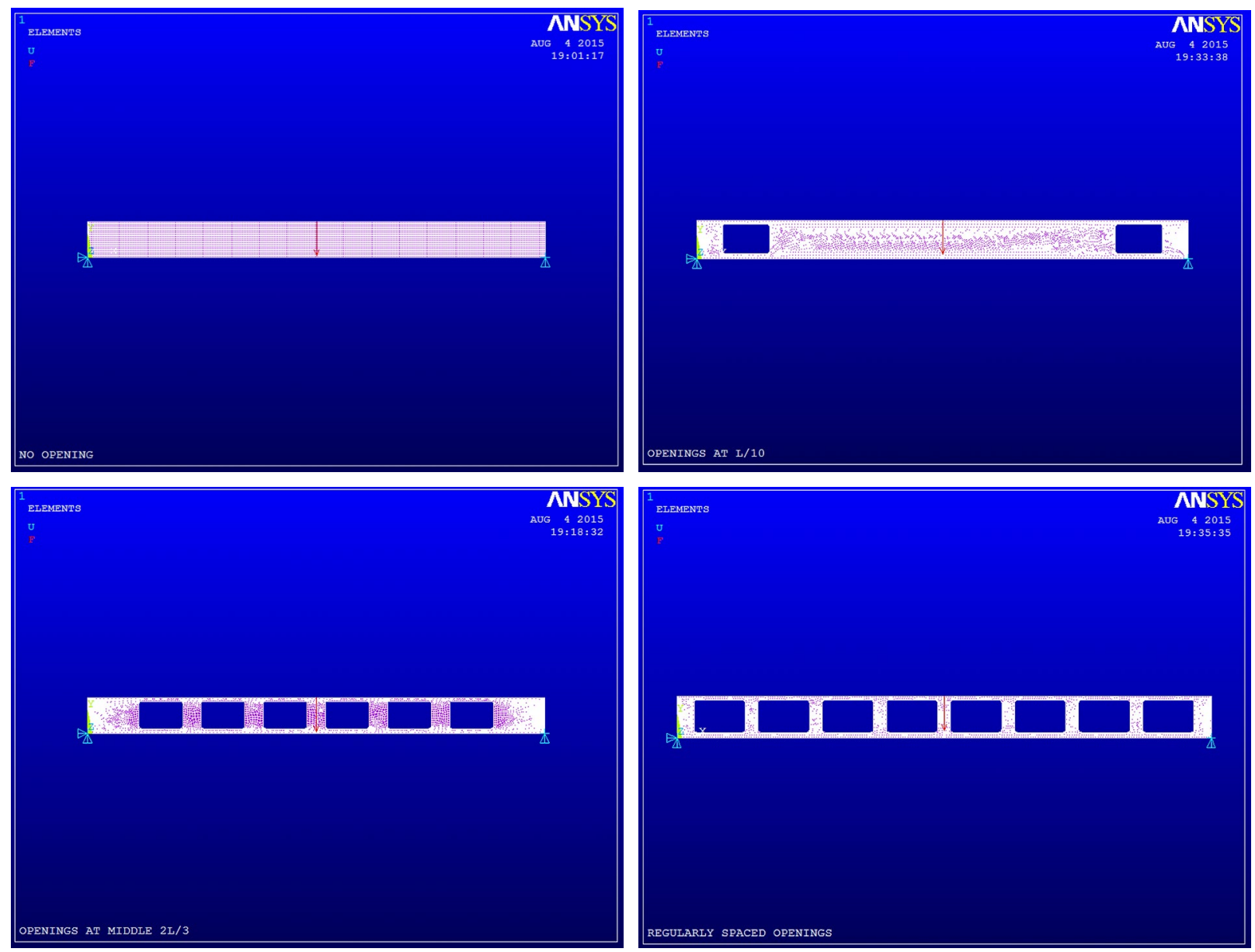

Fig. 19. Position of web openings studied

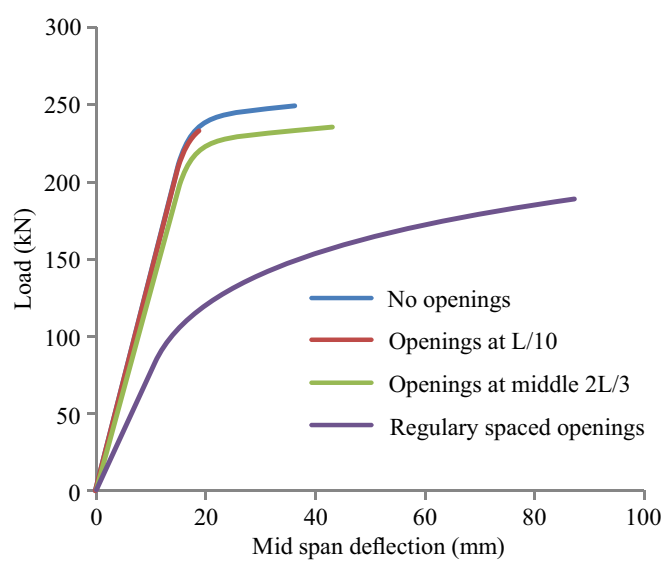

Fig. 20. Load vs mid span deflection for different position of openings 


\section{Acknowledgments}

The research described in this paper was financially supported by the Technical Education Quality Improvement Program (TEQIP-II). The authors are thankful to The Director, Visvesvaraya National Institute of Technology (VNIT), Nagpur for sanctioning the financial approval for the research project described in this paper.

\section{References}

AISC. 1999a. Load and Resistance Factor Design Specification for Structural Steel Buildings American Institute for Steel Construction (with errata incorporated as of September 1, 2002). American Institute of Steel Construction, Chicago, USA.

AISC. 1999b. LRFD Manual of Steel Construction - Part 5: Design of Flexural Members (with errata incorporated as of September 1, 2002). American Institute of Steel Construction, Chicago, USA.

ANSYS User's Manual Release. 2009. Canonsburg.

Bradford, M. A. 1998. Distortional buckling of elastically restrained cantilevers, Journal of Constructional Steel Research 47: 3-18. http://dx.doi.org/10.1016/S0143-974X(98)80003-5

BSI. 2000. Structural Use of Steelwork in Buildings - Part 1: Code of Practice for Design Rolled and Welded Sections. BS-5950. British Standards Institution, UK.

Chung, K. F.; Liu, T. CH.; Ko, A. CH. 2003. Steelbeams with large web openings of various shapes and sizes: an empirical design method using a generalized moment-shear interaction, Journal of Constructional Steel Research 59: 117-120. http://dx.doi.org/10.1016/s0143-974x(03)00029-4

Chung, K. F.; Liu, T. CH.; Ko, A. CH. 2001. Investigation on Vierendeel mechanism in steel beams with circular web openings, Journal of Constructional Steel Research 57: 467-90. http://dx.doi.org/10.1016/S0143-974X(00)00035-3

Chung, K. F. 2012. Recent advances in design of steel and composite beams with web openings, Advances in Structural Engineering 15(9): 1521.

http://dx.doi.org/10.1260/1369-4332.15.9.1521
CSA. 2001. Limit States Design of Steel Structures. S16-01. Canadian Standards Association, Toronto, Ontario.

Ellobody, E. 2011. Interaction of buckling modes in castellated steel beams, Journal of Constructional Steel Research 67(5): 814-25. http://dx.doi.org/10.1016/j.jcsr.2010.12.012

Kerdal, D.; Nethercot, D. A. 1984. Failure modes for castellated beams, Journal of Constructional Steel Research 4: 295-315. http://dx.doi.org/10.1016/0143-974X(84)90004-X

Mohebkhah, A. 2004. The moment-gradient factor in lateraltorsional buckling on inelastic castellated beams, Journal of Constructional Steel Research 60: 1481-1494. http://dx.doi.org/10.1016/j.jcsr.2004.02.002

Pattamad, P.; Thaksin, Th. 2013. Finite element investigation on deflection of cellular beams with various configurations, International Journal of Steel Structures 13(3): 487-494. http://dx.doi.org/10.1007/s13296-013-3008-z

Redwood, R. G.; McCutcheon, J. O. 1969. Beam tests with unreinforced web openings, Journal of the Structural Division, ASCE 94(1): 1-17.

Shrivastava, S. C.; Redwood, R. G. 1977. Web instability near reinforced rectangular holes, in Proceedings of International Association for Bridge and Structural Engineering (IABSE) No. P-6, October 24-26, 1977, Munich, Germany.

Timoshenko, S. P.; Gere, J. M. 1961. Theory of elastic stability. $2^{\text {nd }}$ ed. McGraw-Hill.

Zirakian, T. 2008. Elastic distortional buckling of doubly symmetric I-shaped flexural members with slender webs, Journal of Constructional Steel Research 46: 466-75. http://dx.doi.org/10.1016/j.tws.2007.11.001

Zirakian, T.; Showkati, H. 2006. Distortional buckling of castellated beams, Journal of Constructional Steel Research 62: 863-71. http://dx.doi.org/10.1016/j.jcsr.2006.01.004

U.S. Steel Corporation. 1986. Rectangular, Concentric and Eccentric Reinforced Web Penetrations in Steel Beams-A Design Aid. Rev. ed. ADUSS 27-8482-02. Pittsburgh.

Samadhan G. MORKHADE is a research scholar in Structural Engineering, Dept. of Applied Mechanics, Visvesvaraya National Institute of Technology, India. His research area is analysis of steel beams with web openings.

Laxmikant M. GUPTA is Professor of Structural Engineering in Visvesvaraya National Institute of Technology, India. His current research interests are steel and composite structures, and prestressed steel structure. He has published more than 150 papers in reputed journals/international/national conferences. 